\title{
Sistem Aplikasi Pengelolaan Tugas Akhir Berbasis Mobile
}

\author{
Julianto Simatupang ${ }^{1}$, Muhammad ${ }^{2}$ \\ Manajemen Informatika, Akademi Manajemen Informatika dan Komputer Mahaputra Riau ${ }^{1,2}$ \\ julianto.amp@gmail.com ${ }^{1}$, amp.muhammad090888@gmail.com ${ }^{2}$
}

\section{Article Info}

History :

Dikirim 16 November 2018

Direvisi 08 Februari 2019

Diterima 25 Februari 2019

\section{Kata Kunci:}

Android

Sistem

Aplikasi

Tugas Akhir

Mobile

\begin{abstract}
Abstrak
Pelaksanaan tugas akhir merupakan kegiatan rutin yang dilaksanakan oleh program studi manajemen informatika AMIK Mahaputra Riau. Pengelolaan dan pengorganisasian tugas akhir dengan baik akan mempermudah semua pihak terkait dalam pelaksanaannya. Permasalahan yang ada saat ini, banyaknya prosedur administratif yang harus dilakukan oleh mahasiswa dan proses pengajuan tugas akhir yang masih manual sehingga mengakitbatkan program studi mengalami kesulitan dalam pengelolaan tugas akhir. Misalnya seperti proses penyajian informasi yang membutuhkan waktu yang lama karena harus menghitung satu per satu lembar pengajuan judul yang masuk dan membuat pengumuman hasil seleksi judul melalui majalah dinding kampus. Hal ini kurang efektif dan efisien sehingga diusulkan penerapan teknologi dalam pengelolaan tugas akhir. Oleh karena itu pengembangan sistem aplikasi menjadi solusi untuk pengelolaan tugas akhir sehingga dapat mempermudah mengkordinir dan mengelola tugas akhir. Sistem aplikasi yang dimaksud adalah berbasis mobile khususnya android sehingga mahasiswa kapan dan dimana saja dapat mengakses dan melihat informasi terkait tugas akhir dari smartphone mereka tanpa batas waktu dan jarak.
\end{abstract}

(C) This work is licensed under a Creative Commons AttributionShareAlike 4.0 International License.

\author{
Koresponden: \\ Julianto Simatupang, \\ Program Studi Manajemen Informatika, \\ AMIK Mahaputra Riau, \\ J1. HR. Subrantas No.77, Pekanbaru, Indonesia, 28291 \\ Email : julianto.amp@Gmail.com
}

\section{PENDAHULUAN}

Tugas akhir merupakan karya ilmiah yang disusun oleh mahasiswa tingkat akhir sebagai syarat untuk menyelesaikan studi pada pendidikan tinggi. Dalam proses penyusunan tugas akhir akan melibatkan beberapa komponen pada perguruan tinggi yaitu mahasiswa, dosen dan baak serta pengelola program studi. Pentingnya pembuatan tugas akhir tentu menjadi perhatian utama bagi seluruh mahasiswa, khususnya mahasiswa yang duduk pada tingkat akhir. Pengelolaan tugas akhir yang baik tentu akan mempermudah para pihak yang terlibat dalam proses pelaksanaannya.

Pengelolaan tugas akhir pada perguruan tinggi secara umum masih dilakukan dengan cara manual, yaitu menggunakan kertas menjadi media mulai dari pengajuan judul, pelaksanaan bimbingan sampai dengan pengolahan data hasil tugas akhir. [Amik Mahaputra Riau (AMP)] adalah salah satu perguruan tinggi bidang vokasi yang berada di provinsi riau. Pada saat ini proses pengelolaan tugas akhir mahasiswa masih dilakukan dengan cara konvensional (mengapa AMIK 
Mahaputra Riau) yaitu, semua proses pengelolaan tugas akhir masih dilakukan dengan mencatat di kertas, sehingga menimbulkan beberapa masalah dalam pelaksanaannya, Seperti pengajuan judul, mahasiswa harus mengisi formulir pengajuan judul kemudian diserahkan ke program studi, oleh pogram studi kadang kala formulir tersebut hanya diarsipkan begitu saja sehingga formulir tersebut tercecer dan bahkan hilang. Oleh karena itu tidak jarang mahasiswa harus mengisi kembali formulir pengajuan judul. Pendataan mahasiswa yang telah mengajukan judul, pada proses pendataan ini program studi harus memeriksa dan mencatat satu persatu formulir yang diajukan oleh mahasiswa sehingga pendataannya membutuhkan waktu yang relatif lama dan terkesan sangat lambat.

Beberapa permasalahan, selain daripada yang dipaparkan diatas juga ditemukan masalah seperti, Pengumuman hasil pengajuan judul, program studi harus memeriksa dan mencatat satu persatu berita acara hasil seminar proposal, kemudian membuat rekap seminar hasil sehingga prosesnya juga membutuhkan waktu yang relatif lama. Komposisi judul sesuai kompetensi, proses pengelompokan judul juga masih dilakukan dengan memeriksa satu persatu judul yang diajukan oleh mahasiswa, dan kemudian program studi merekap bidang kompetensi judul yang diajukan. Sehingga pemantuannya menjadi lemah, oleh karena itu terjadi ketimpangan komposisi judul sesuai kompetensi. Misalnya kompetensi judul desktop bisa mencapai $70 \%$ sementara web dan jaringan hanya $30 \%$ dari jumlah mahasiswa yang mengikuti tugas akhir.

Berdasarkan uraian permasalahan diatas, pengembangan sistem Aplikasi berbasis Teknologi Mobile menjadi solusi dalam pemecahan masalah pengelolaan tugas akhir. Karena sistem aplikasi dengan teknologi mobile memiliki keunggulan diantaranya dapat diakses kapan saja dan dimana saja sehingga monitoring pelaksanaan dan pengelolaan tugas akhir dapat dilakukan dengan cepat, tepat dan akurat, serta mampu meningkatkan efisiensi dan efektifitas kerja pihak-pihak yang terkait. Selain itu juga dapat mengurangi penggunaan kertas, sehingga perguruan tinggi dapat menekan biaya pengadaan kertas. Tujuan pengembangan aplikasi berbasis mobile

\section{METODE PENELITIAN}

\subsection{Tahapan Penelitian}

Adapun tahapan penelitian yang dilakukan dibagi atas beberapa tahapan sebagai berikut :

Tahapan Studi Pustaka :

a. Inisialisasi

Melakukan pengumpulan bahan literatur dan informasi berkaitan dengan judul penelitian.

b. Identifikasi Masalah

Melakukan identifikasi tentang masalah apa yang akan dibahas berdasarkan literatur dan informasi yang telah diperoleh.

c. Kajian Literatur

Mempelajari literatur yang akan digunakan sebagai kajian teori dalam penelitian ini.

Tahapan menentukan dan Menyusun Instrumen Penelitian :

a. Pengumpulan data

Mengumpulkan data primer dan data sekunder yang diperoleh melalui wawancara, quesioner dan observasi.

b. Pengelompokan data

Mengelompokkan data-data sesuai dengan pengelolaan tugas akhir yang ada.

c. Analisa Data

Melakukan analisa data berdasarkan hasil pengelompokan data dengan menggunakan tahapan yang ada pada tahapan yang digunakan pada penelitian ini.

\subsection{Teknik Pengumpulan Data}

Data yang digunakan dalam penelitian ini adalah data primer dan data sekunder. Data primer adalah data yang diproleh secara langsung dari sumber asli (tidak melalui perantara). Data primer pada penelitian ini diproleh melalui wawancara, quesioner dan observasi, yaitu :

1. Wawancara langsung dengan mahasiswa tingkat akhir yang sedang melaksanakan tugas akhir.

2. Menyebarkan quesioner kepada mahasiswa tingkat akhir yang sedang melaksanakan tugas akhir. 
3. Mengamati aktivitas dan kegiatan-kegiatan yang dilakukan oleh mahasiswa tingkat akhir yang akan dan sedang melaksanakan tugas akhir.

Data sekunder merupakan sumber data penelitian yang diperoleh peneliti secara tidak langsung melalui media perantara. Data sekunder umumnya berupa bukti, catatan atau laporan histori yang telah tersusun dalam arsip. Data sekunder pada penelitian ini diproleh melalui pengambilan data terkait, yaitu :

1. Mengumpulkan data hasil wawancara mahasiswa tingkat akhir yang akan dan sedang melaksanakan tugas akhir.

2. Mengumpulkan data quesioner yang sudah di isi oleh mahasiswa tingkat akhir.

3. Mengumpulkan data mahasiswa tingkat akhir yang sedang tugas akhir.

\subsection{Metode Perancangan Sistem}

Metode yang digunakan dalam penelitian ini adalah System Development Life Cycle (SDLC). Metode ini adalah metode klasik dalam pengembangan sistem informasi. Siklus hidup sistem terdiri dari serangkaian tugas yang erat mengikuti langkah-langkah pendekatan sistem karena tugas-tugas tersebut mengikuti pola yang teratur dan dilakukan secara top down. Siklus hidup sistem sering disebut sebagai pendekatan air terjun (waterfall approach) bagi pembangunan dan pengembangan system [5]. Hal ini sesuai dengan tujuan penelitian, yaitu untuk mengembangkan sistem aplikasi pengelolaan tugas akhir. Metode ini digunakan untuk menghasilkan produk tertentu dengan menguji keefektifan produk tersebut. Berikut adalah fase/tahapan pengembangan sistem dengan menggunakan metode waterfall:

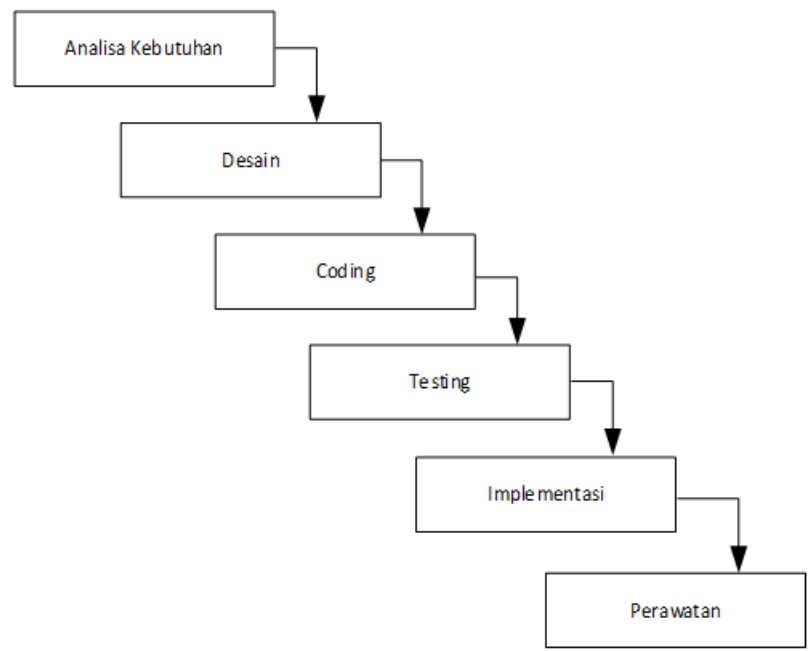

Gambar 1. Siklus Hidup Pengembangan Sistem

Tahapan ini merupakan urutan langkah-langkah dalam pengembangan sistem informasi, yang di desain secara terstruktur atau sistematis. Berikut penjelasan siklus hidup pengembangan sistem: [3]

1. Analisa Kebutuhan

Fase ini menjelaskan bahwa awal sekali melakukan pengembangan sistem terlebih dahulu melakukan analisa terhadap masalah yang dihadapi, kemudian menentukan requirement berdasarkan kebutuhan.

2. Desain

Fase ini melakukan perancangan sistem berdasarkan hasil analisa dan kebutuhan sistem. Kemudian diterapkan pemodelan sistem untuk menggambarkan bagaimana proses bisnis yang ada pada sistem yang akan dibangun.

3. Coding 
Pada tahap ini dilakukan pemilihan bahasa pemrograman yang sesuai untuk sistem yang akan dibangun. Kemudian dilakukan penulisan script program (Coding) sesuai alur logika program, sehingga proses bisnis dapat ditransformasikan ke dalam bahasa pemrograman.

4. Testing

Melakukan pengujian terhadap produk yang dibuat apakah sudah sesuai dengan kebutuhan user dan proses bisnis. Dalam hal ini dilakukan beberapa metode testing, sehingga hasil benar-benar sesuai.

5. Implementasi

Implementasi merupakan wujud dari beberapa tahapan sebelumnya. Dalam hal ini User bisa mengoperasikan langsung produk.

6. Pemeliharaan

Merupakan tahapan penting karena sejatinya pemeliharaan sistem menjadi tugas dari setiap user untuk menjaga agar sistem dapat dioperasikan dengan kondisi prima.

\subsection{Android}

Menurut Nazruddin, Android adalah sebuah sistem operasi untuk perangkat mobile berbasis linux yang mencakup sistem operasi, middleware, dan aplikasi. Android menyediakan platform terbuka bagi para pengembang untuk menciptakan aplikasi mereka sendiri untuk digunakan oleh bermacam piranti bergerak [1]. Dalam defenisi yang lain Android Studio adalah Integrated Development Enviroment (IDE) untuk sistem operasi Android, yang dibangung diatas perangkat lunak JetBrains IntelliJ IDEA dan didesain khusus untuk pengembangan Android. IDE ini merupakan pengganti dari Eclipse Android Development Tools (ADT) yang sebelumnya merupakan IDE utama untuk pengembangan aplikasi android.[4]

1. Android Platform Masa Depan

a. Android merupakan salah satu platform mobile pertama yang lengkap, terbuka, dan bebas. Lengkap (Complete Platform): Memungkinkan para desainer untuk melakukan pendekatan secara komprehensif ketika mereka sedang mengembangkan platform android. Android juga merupakan sistem operasi yang aman dan banyak menyediakan tools dalam membangun software dan pengembangan aplikasi.

b. Terbuka (Open Source Platform) Platform android disediakan melalui lisensi opensource. Pengembang dapat dengan bebas untuk mengembangkan aplikasi.

c. Free (Free Platform) android adalah platform/aplikasi yang bebas untuk develop. Tidak ada lisensi atau biaya royalti untuk dikembangkan pada platform android. Aplikasi android dapat didistribusikan dan diperdagangkan dalam bentuk apapun.

2. Fundamental Aplikasi

Aplikasi android ditulis dalam bahasa pemrograman java. Kode java dikompilasi bersama dengan data file resource yang dibutuhkan oleh aplikasi dimana prosesnya dipackage oleh tools yang dinamakan "apt tools" ke dalam paket android sehingga menghasilkan file dengan ekstensi apk. File apk inilah yang disebut dengan aplikasi, dan nantinya dapat di install di perangkat mobile. Ada empat jenis komponen pada aplikasi android yaitu :
a. Activities
b. Service
c. Broadcast Reciever
d. Content Provider

3. Kelebihan dan kekurangan android

Beberapa kelebihan android sebagai berikut :

a. Switching dan multitasking yang lebih baik, Android sangat mendukung multitasking aplikasi, kini hal tersebut kembali ditingkatkan. Dalam Honeycomb penggguna dapat dengan mudah berpindah aplikasi hanya dengan menyentuh sebuah icon pada system bar.

b. Kapasitas yang lebih baik untuk beragam widget Kapabilitas terhadap beragam widget dijanjikan bakal makin memanjakan para penggunanya. Contohnya widget untuk email Gmail yang dipamerkan Google, pengguna tidak perlu membuka aplikasi Gmail untuk melihat isi di dalamnya. 
c. Peningkatan kemampuan

copy-paste Beberapa seri Android terdahulu memang sudah bisa melakukan copypaste, namun beberapa pengguna masalah pemilihan teks yang agak sulit. Kini hal tersebut coba diselesaikan, selain copy-paste Google juga menambah share it pada teks yang diseleksi.

d. Browser Crome Lebih Cepat

Ada satu fitur yang hilang dalam browser Chrome yang diletakkan pada Android terdahulu, kemampuan Tab. Chrome yang ada di Honeycomb kini dapat melakukan hal tersebut. Selain itu pengguna juga bisa mensinkronisasi antara browser di ponsel dengan Crome yang ada di komputer.

e. Notifikasi yang Mudah

Terdengar. Dengan layar yang lebih besar, otomatis membua Google lebih leluasa menempatkan notifikasi pada layar.

f. Peningkatan Drag and Drop serta Multitouch Ukuran layar yang lebih besar, menuntut Google untuk meningkatkan kemampuan multitouch di dalam Android, tak terkecuali fitur drag and drop. Pada demo yang ditayangkan, pengguna bisa melakukan drag and drop untuk memindahkan email di dalam aplikasi Gmail.

Adapun Kekurangan Android

a. Koneksi Internet yang terus menerus. Kebanyakan ponsel Android memerlukan koneksi internet yang simultan atau terus menerus aktif, itu artinya anda harus siap berlangganan paket GPRS yang sesuai dengan kebutuhan dan batre yang boros karena GPRS yang terus menyala.

b. Iklan. Aplikasi di Ponsel Android memang bisa didapatkan dengan mudah dan gratis, namun konsekuensinya di setiap Aplikasi tersebut, akan selalu ada Iklan yang terpampang.

4. Android and SDK Tool (Software Development Kit)

Android SDK mencakup perangkat tools pengembangan yang komprehensif. Android SDK terdiri dari debugger, libraries, handset emulator, dokumentasi, contoh kode program dan tutorial. Saat ini Android sudah mendukung arsitektur x86 pada Linux (distribusi Linux apapun untuk desktop modern), Mac OS X 10.4.8 atau lebih, Windows XP atau Vista.Persyaratan mencakup JDK, Apache Ant dan Python 2.2 atau lebih. IDE yang didukung secara resmi adalah Eclipse 3.2 atau lebih dengan menggunakan plugin Android Development Tools (ADT), dengan ini pengembang dapat menggunakan IDE untuk mengedit dokumen Java dan XML serta menggunakan peralatan command line untuk menciptakan, membangun, melakukan debug aplikasi Android dan pengendalian perangkat Android (misalnya reboot, menginstal paket perangkat lunak).

\subsection{Unified Modeling Language (UML)}

Pengembangan sistem aplikasi ini menggunakan pemodelan sistem dengan UML. UML adalah bahasa untuk menspesifikasi, memvisualisasi, mambangun dan mendokumentasikan artifact (bagian dari informasi yang digunakan atau dihasilkan oleh proses pembuatan perangkat lunak, artifact tersebut dapat berupa model, deskripsi atau perangkat lunak) dari sistem perangkat lunak, seperti pada pemodelan bisnis dan sistem non perangkat lunak lainnya. UML menyediakan notasinotasi yang membantu memodelkan sistem dari berbagai perspektif. Pada UML 2.3 terdiri dari 13 diagram yang dikelompokkan dalam 3 kategori.[5] Berikut gambar diagram UML : 


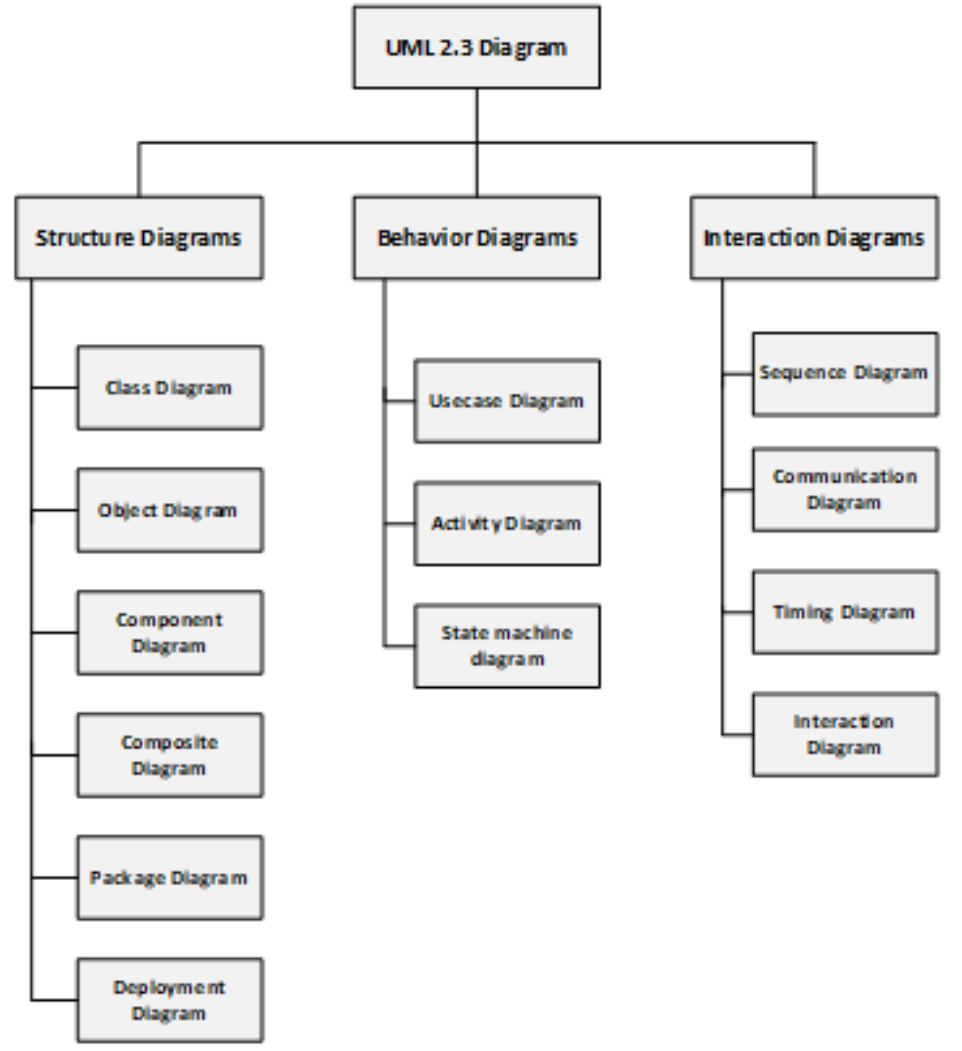

Gambar 2. Diagram UML

\subsection{MySQL}

MySQL merupakan sebuah software sistem manajemen database yang banyak digunakan dalam aplikasi berbasis windows maupun web. Keunggulan MySQL dibandingkan database lain adalan free dan open source. Sistem Database MySQL mendukung beberapa fitur seperti multithreaded, multi-user, dan SQL database management system (DBMS). Database ini dibuat untuk keperluan sistem database yang cepat, andal dan mudah digunakan.[6]

\subsection{Sistem Aplikasi}

Menurut Jogiyanto (2005:12), aplikasi adalah penggunaan dalam suatu komputer, instruksi (instructiom) atau pernyataan (statement) yang disusun sedemikian rupa sehingga komputer dapat memproses input menjadi output.

Menurut kamus besar Bahasa Indonesia (2005:52), “Aplikasi adalah penerapan dari rancang sistem untuk mengolah data yang menggunakan aturan atau ketentuan bahasa pemrograman tertentu".

Dari definisi di atas dapat disimpulkan bahwa Sistem aplikasi merupakan suatu program komputer yang dibuat secara khusus untuk mengerjakan atau menyelesaikan kebutuhan atau tugas pengguna dengan spesifik.

\section{HASIL DAN PEMBAHASAN}

Proses bisnis pengelolaan tugas akhir yang merupakan dasar yang dijadikan acuan untuk melakukan implementasi sistem aplikasi pengelolaan tugas akhir berbasis mobile pada AMIK Mahaputra. Proses yang Pertama sekali dilakukan Para aktor yang terlibat dengan sistem sebelum mengoperasikan aplikasi lebih jauh adalah melakukan login. Dalam hal ini sistem akan memverifikasi setiap username dan password serta level login dari masing-masing user. Apabila login berhasil maka sistem akan menampilkan dashboard sesuai dengan level masing-masing. Pengembangan sistem ini dilakukan dengan menggunakan 2 halaman interface yaitu web dan mobile android. Dimana untuk admin yang mengelola langsung tugas akhir berada pada laman WEB admin. Sementara untuk mahasiswa di desain dalam interface mobile android. Dalam hal ini 
siswa akan melakukan pengajuan tugas akhir lewat smartphone mereka. Adapun desain interface dari masing-masing user adalah sebagai berikut :

1. Admin Interface

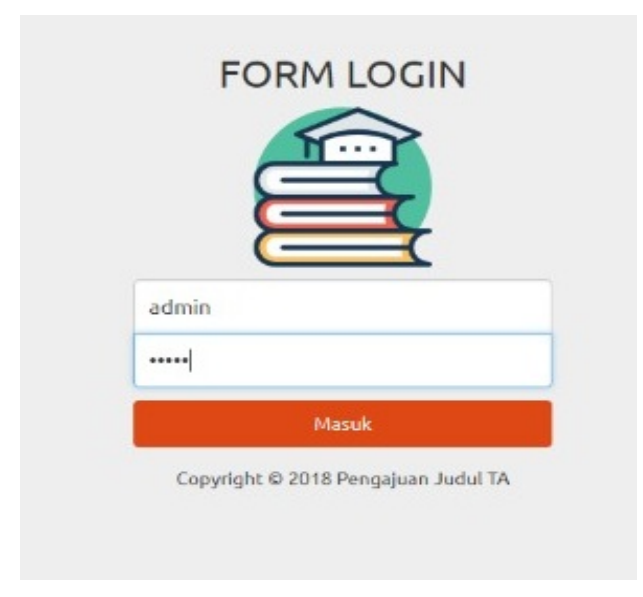

(a)

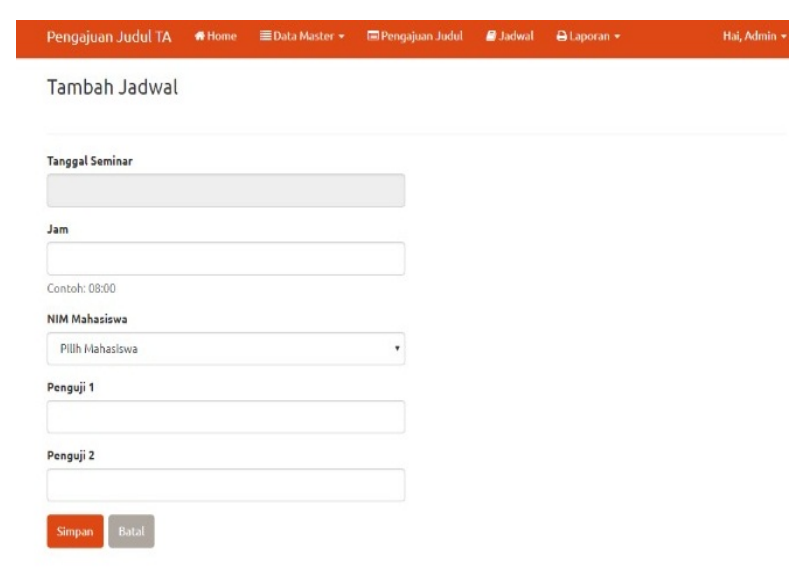

(b)

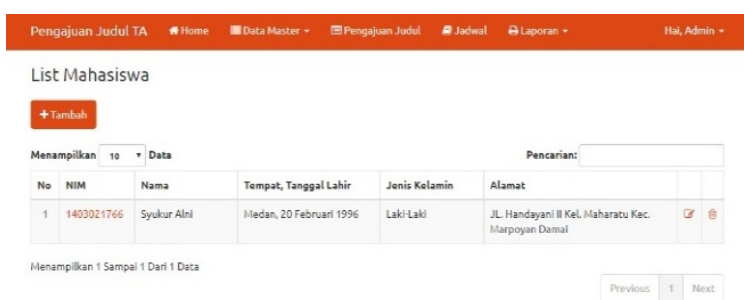

(c)

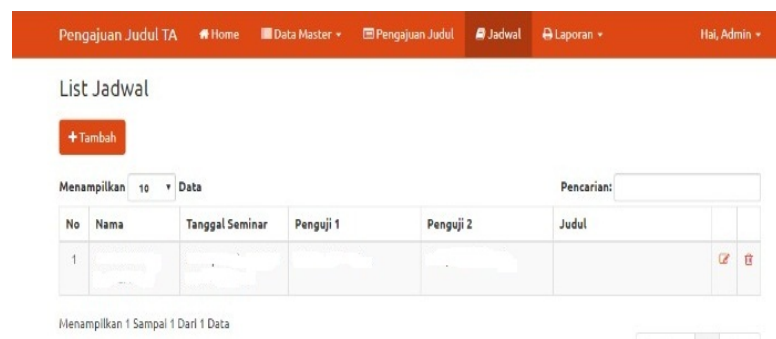

(d)
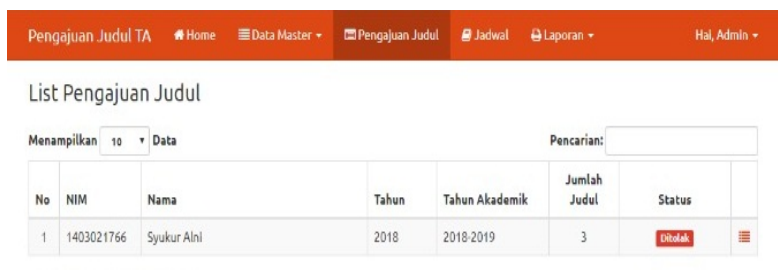

Menampilkan 1 Sampai 1 Dari 1 Data

(e)

Gambar 3. Tampilan Aplikasi pengelolaan tugas akhir: (a) Login, tampilan awal aplikasi sebelum masuk ke menu utama; (b) Tampilan Tambah Jadwal, History; (c) Tampilan Menu "List Mahasiswa"; (d) Tampilan List Jadwal; (e) Tampilan List Pengajuan Judul. 
a. Login

Tampilan Login Merupakan halaman pintu masuk admin untuk mengoperasikan aplikasi ini lebih jauh. Halaman ini di peruntukkan khusus untuk admin yang langsung mengelola tugas akhir. Proses login dilakukan dengan menginputkan usename dan password, kemudian sistem akan memverifikasi username dan password. Apabila login berhasil akan masuk ke halam dashboard, sebaliknya bila login gagal maka menampilkan pesan kesalahan.

b. Tambah Jadwal

Halaman ini digunakan untuk mengelola jadwal seminar. Pada halaman ini juga terdapat beberapa tombol fungsi yang dapat digunakan untuk manipulasi data jadwal seminar.

c. List Mahasiswa

Halaman List Mahasiswa digunakan untuk mengolah data mahasiswa. Pada halaman ini terdapat tombol untuk tambah data mahasiswa, dan juga view data mahasiswa.

d. List Jadwal

Halaman List jadwal digunakan untuk menampilkan data jadwal. Halaman ini juga terdapat kolom untuk pencarian data. Kolom pencarian digunakan untuk mempermudah admin dalam mencari data mahasiswa yang telah masuk dalam jadwal seminar.

e. List Pengajuan Judul

Halaman ini digunakan untuk menampilkan data judul yang diajukan oleh mahasiswa. Pada halaman ini juga admin dapat mengubah status judul yang diajukan.

2. Interface Mahasiswa

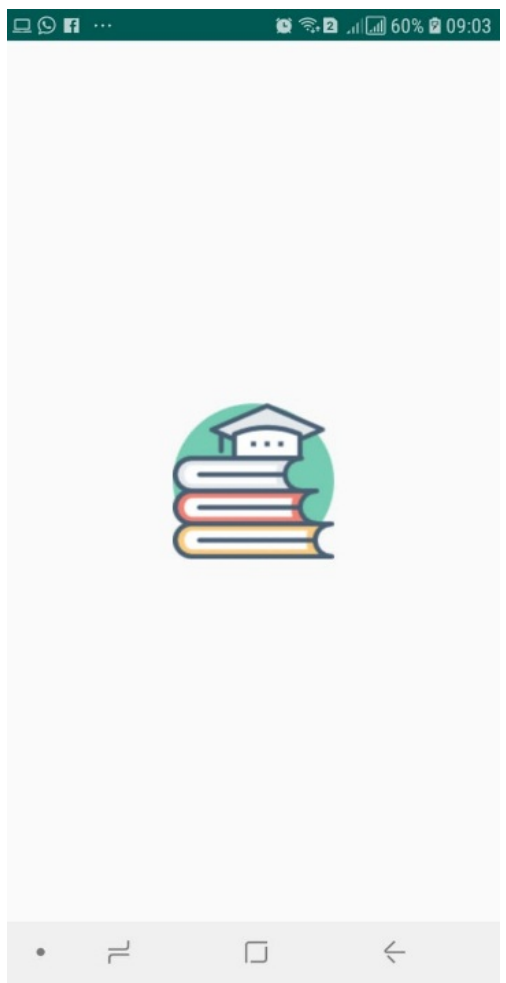

(a)

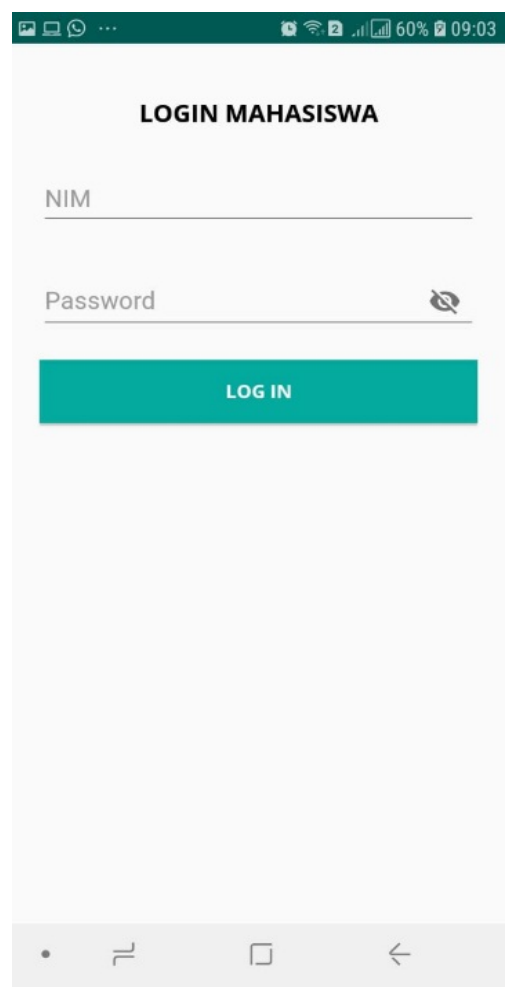

(b) 


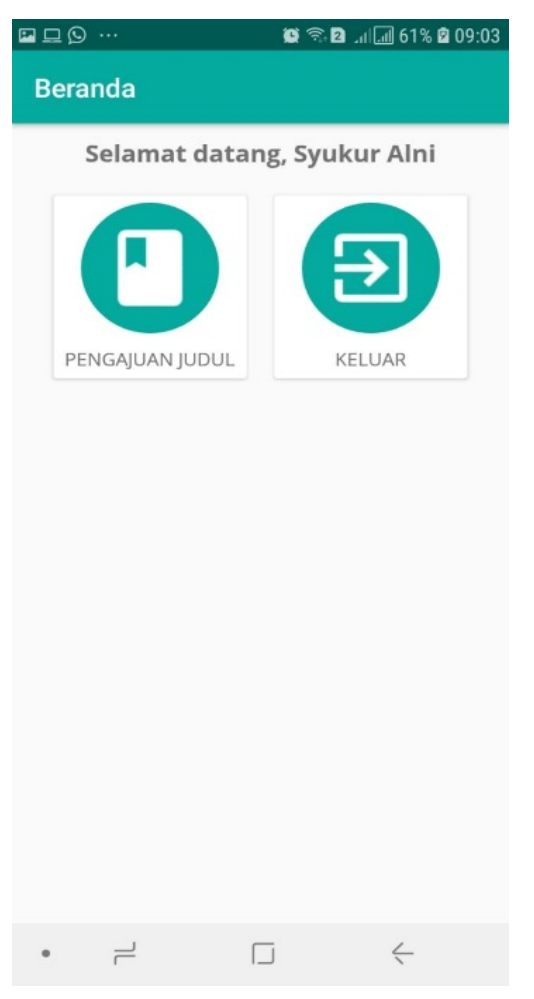

(c)

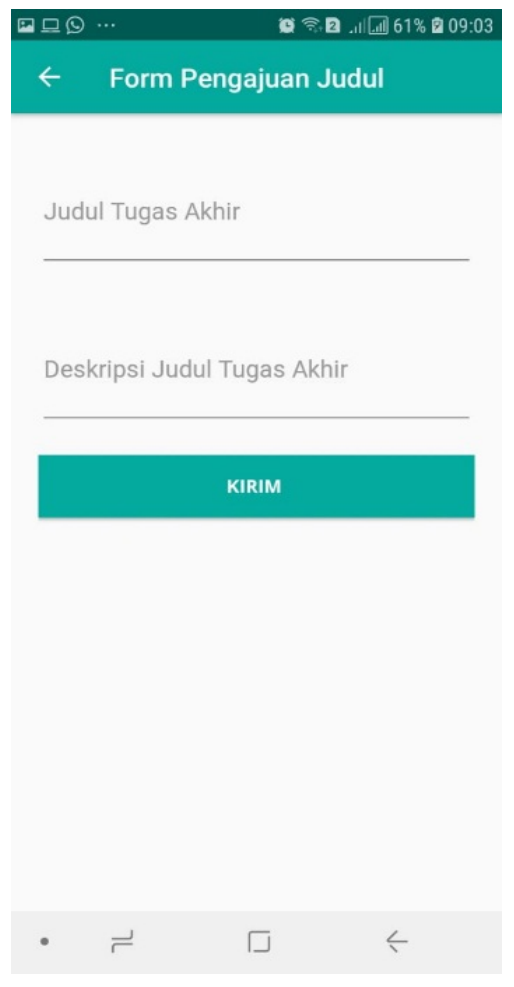

(d)

Gambar 4. Tampilan Interface Mahasiswa (a) Icon interface pengajuan judul (b) Tampilan Login; (c) Tampilan Beranda (d) Tampilan Form Pengajuan Judul.

a. Icon Interface Pengajuan judul

Untuk masuk halaman pengajuan judul, mahasiswa terlebih dahulu menekan tombol icon Interface pengajuan judul.

b. Login Mahasiswa

Merupakan halaman login untuk mahasiswa. Setiap mahasiswa wajib melakukan login sebelum mengajukan judul tugas akhir. Pada halaman ini terdapat kolom username yang diwakili dengan nim dan password. Sistem akan melakukan verifikasi untuk setiap mahasiswa yang login ke sistem apabila login berhasil akan masuk ke halam menu pengajuan judul sebaliknya apabila salah maka akan tetap menampilkan form login.

c. Beranda

Merupakan menu untuk menampilkan pengajuan judul. Dalam halaman beranda ini terdapat 2 menu pilihan yaitu pengajuan judul atau keluar. Apabila menekan icon pengajuan judul maka akan masuk ke form pengajuan judul. Dan apabila memilih keluar, maka akan logout dari sistem dan kembali ke menu utama.

d. Form Pengajuan Judul

Form ini digunakan menginput data judul tugas akhir yang diajuakan mahasiswa. Terdapan satu tombol kirim yang berfugsi untuk meyimpan dan memindai judul yang input.

\section{Pengujian Sistem}

Pengujian aplikasi ini dilakukan dengan menggunakan pengujian black box. Pengujian black box bertujuan untuk mengetahui fungsi perangkat lunak dalam pengoperasian aplikasi dan hasil uji black box dari aplikasi. Tabel 1 dan tabel menunjukkan hasil uji coba black box. Berdasarkan tabel tersebut, virtual button yang digunakan sudah berjalan sesuai dengan yang diharapkan oleh user atau pengguna. 
Tabel 1. Hasil Uji Coba Black Box Halaman Admin

\begin{tabular}{lllll}
\hline No. & Pengujian & Input & Output & Kesimpulan \\
\hline 1 & Login & Klik Login & Tampilan Login & Tampilan $\sqrt{ }$ \\
\hline 2 & List Mahasiswa & Klik List Mahasiswa & Tampilan List Mahasiswa & Tampilan $\sqrt{ }$ \\
\hline 3 & List Jadwal & Klik List Jadwal & Tampilan List Jadwal & Tampilan $\sqrt{ }$ \\
\hline 4 & List Pengajuan Judul & Klik List Pengajuan Judul & $\begin{array}{l}\text { Tampilan List Pengajuan } \\
\text { Judul }\end{array}$ & Tampilan $\sqrt{ }$ \\
\hline
\end{tabular}

Tabel 2. Hasil Uji Coba Black Box Halaman Mahasiswa

\begin{tabular}{lllll}
\hline No. & Pengujian & Input & Output & Kesimpulan \\
\hline 1 & Login Mahasiswa & Klik Login Mahasiswa & Tampilan Login Mahasiswa & Tampilan $\sqrt{ }$ \\
\hline 2 & Beranda & Klik Beranda & Tampilan Beranda & Tampilan $\sqrt{ }$ \\
\hline 3 & Pengajuan Judul & Klik Pengajuan Judul & Tampilan Pengajuan Judul & Tampilan $\sqrt{ }$ \\
\hline
\end{tabular}

\section{KESIMPULAN}

Sistem aplikasi pengajuan tugas akhir berbasis Android dapat dijadikan pilihan tepat dalam membantu menyelesaikan persoalan mengenai pengelolaan tugas akhir. Kemampuan-kemampuan yang bisa diandalkan dari aplikasi tersebut antara lain :

1. Kemudahan dalam penggunaan

2. Inputan data mahasiswa, data jadwal, dan data judul. Mahasiswa juga dimudahkan dalam pengajuan tugas akhir lewat aplikasi mobile. Berjalan sesuai dengan permintaan dan kebutuhan para pengguna sistem.

\section{UCAPAN TERIMA KASIH}

Penulis mengucapkan terimakasih yang sebesar-besarnya kepada para pihak yang telah mendukung dan mendorong terlaksananya penelitian ini, baik moril maupun materil. Secara khusus kepada kemenristek dikti yang telah mendukung penuh pendanaan penelitian ini. Tidak lupa juga teman-teman sejawat yang memberikan motivasi. Mudah-mudahan hasil penelitian bermanfaat bagi kita semua, khususnya para peneliti yang fokus pada sistem berbasis android. Sungguh sangat berterima kasih kepada teman

\section{DAFTAR PUSTAKA}

[1] Amin, Ruhul. "Aplikasi akademik online berbasis mobile android pada Universitas tama jagakarsa." Jurnal Sains dan Teknologi Utama, Volume XI, Nomor 1. (2016).

[2] https://kbbi.web.id, 2018.

[3] Jogiyanto, Hartono. Analisis \& Desain Sistem Informasi, Andi Offset, Yogyakarta, 2013

[4] Nazruddin, Safaat., H, Pemrograman Aplikasi Mobile Smart phone Dan Tablet PC Berbasis Android, Bandung, Informatika, 2015.

[5] Rosa dan Salahuddin, "Rekayasa Perangkat Lunak terstruktur dan berorientasi Objek", Bandung, Informatika, 2013.

[6] Wahana Komputer, "Panduan Belajar MySQL Database Server", Jakarta, 2010. 